DOI: https://doi.org/10.32839/2304-5809/2021-3-91-61

УДК 342.591

Мельченко B.I. ${ }^{1}$

Донбаська державна машинобудівна академія

Деркаченко Ю.В. ${ }^{2}$

ПВНЗ «Міжнародний науково-технічний університет імені академіка Юрія Бугая»

\title{
ОСНОВНІ НАУКОВІ ПІДХОДИ ТЛУМАЧЕННЯ ПОНЯТТЯ КОРУПЦІЯ
}

Анотація. Корупція негативно впливає насамперед на реалізацію прав народу (принцип рівності громадян перед літерою закону). Поширюючись на майже всі сфери життя, корупційні злочини заважають мотивувати українщів до гідного життя, прищеплювати повагу до правозахисної системи. У населення через викривлення поняття корупщії, як негативного явища, недостатньо прагнень у дотриманні правопорядку. Корупційні правопорушення стосуються кожного громадянина України, бо через злочинну діяльність страждає якість життя, зменшуеться рівень доходів через тіньову економіку. Корупція істотно підвищуе криміногенну обстановку в країні, деморалізуючи суспільне ставлення до діянь чиновників, високопосадовців. Громадяни України не поспішають втручатися у боротьбу з корупційними складовими життя через формування моральних деформацій сприйняття корупщії. Успішне розв'язання корупції в Україні надзвичайно важлива проблема. Для успішної антикорупційної діяльності знадобиться поглиблене вивчення корупщії, виходячи з принщипів системної методології, використовуючи позищії юридичних і політичних інституцій, соціально-фрілософрьких, економічних наук, сощіологічних досліджень стосовно змісту корупщії, відношення суспільства до корупщійних діянь. Для ефективної боротьби з корупцією необхідно провести грунтовне дослідження задля чіткого розуміння суті цього явища. Досліджуючи інформацію 3 аналітичних джерел (офіційних документів), можна зробити наступний висновок: корупційна діяльність в Україні тісно переплітається з організованими злочинами, правопорушеннями в економічній сфері. Ці ж дані є і в відомостях, які подаються в прогнозах, програмах, що націлені на боротьбу з суспільно-небезпечними злочинними проявами.

Ключові слова: корупція, хабарництво, державне управління, вища освіта.

Melchenko Vitaliy

Donbass State Machine-Building Academy

Derkachenko Yuliia

Academician Y. Bugay International Scientific Technical University

\section{MAIN SCIENTIFIC APPROACHES OF INTERPRETATION OF THE CONCEPT OF CORRUPTION}

Summary. Corruption has a negative impact primarily on the realization of the rights of the people (the principle of equality of citizens before the letter of the law). Extending to almost all spheres of life, corruption crimes hinder motivating Ukrainians to live a dignified life, instilling respect for the human rights system. Due to the distortion of the concept of corruption as a negative phenomenon, the population lacks the desire to maintain law and order. Corruption offenses affect every citizen of Ukraine, because the quality of life suffers due to criminal activity, the level of income decreases due to the shadow economy. Corruption significantly increases the criminogenic situation in the country, demoralizing public attitude to the actions of officials and high-ranking officials. Citizens of Ukraine are in no hurry to intervene in the fight against corruption in life through the formation of moral distortions in the perception of corruption. Successfully tackling corruption in Ukraine is an extremely important issue. Successful anti-corruption activities will require in-depth study of corruption, based on the principles of systemic methodology, using the positions of legal and political institutions, socio-philosophical, economic sciences, sociological research on the content of corruption, society's attitude to corruption. In order to effectively fight corruption, it is necessary to conduct a thorough study in order to clearly understand the essence of this phenomenon. Examining the information from analytical sources (official documents), we can draw the following conclusion: corruption in Ukraine is closely intertwined with organized crime, offenses in the economic sphere. The same data are available in the information provided in the forecasts, programs aimed at combating socially dangerous criminal acts. The aim of the study. Drawing on the modern views of scientists to study the nature of corruption. Methods, object and subject of research. The following methods were used in the study: comparative analysis, systematization of modern scientific works and legislation. The subject of the research is the norms of anti-corruption legislation, specialized literature concerning the problems of effective counteraction to corruption offenses, normative-legal acts.

Keywords: corruption, bribery, public administration, higher education.

Постановка проблеми. В Україні є багато проблемних моментів у всіх сорерах життя. Одна 3 найгостріших проблем, що стоїть перед суспільством країни (суб'єктами), - корупція. Розвиток України гальмуе саме корупція, негативно впливаючи на суспільство в цілому, руйнуючи окремі особистості, у яких викривляеться сприйняття відповідних хабарницьких правопорушень.

Наразі у всіх владних інституціях можна побачити корупційні злочини, які вчиняе чимало

${ }^{1}$ ORCID: https://orcid.org/0000-0001-5492-8902

${ }^{2}$ ORCID: https://orcid.org/0000-0002-3019-9730 
громадських діячів, політиків та інших державних службовців. Наочно оцінити негативний вплив корупції на становлення громадянського суспільства може кожен українець. Цей вплив з кожним днем стає все більш помітним та непоправним, бо корупція форомуе справжню загрозу нащіональній безпеці держави.

Аналіз досліджень та публікацій. Багато вітчизняних дослідників та науковців займаються тривалий час вивченням поняття корупції, ㄲï сутності. Серед найбільш цікавих аналітичних праць з вивчення питань корупційної діяльності та протидії хабарництву можна виділити публікації наступних науковців: А.Я. Естрін, Ю.А. Коміссарчук, В.В. Побережний, І.Ю. Тимофеєва, Є.В. Невмержицький, А.С. Політова, М.В. Фоміна, В.І. Франчук, Л.Г. Коваль, Н.В. Кузнецова, В.О. Криволапчук, С.М. Клімова, В.В. Кузьменко та інші.

Не дивлячись на існування багатьох напрацювань у питанні корупщії та її протидії, на науковому рівні ця проблема вивчена недостатньо. Недопрацьованими залишаються досліди 3 питань корупщійних діянь в залежності від їх впливу на суспільство та життя, сдрер їх розповсюдження. Аналізуючи хабарництво існуючим підходом (через обмежене законодавством коло впливу), виникнення корупційних зв'язків серед державних службовців приватного сектору та посадовців виключає їх відповідальність за вчинення корупційних злочинів. Через це страждає ефективність проведення антикорупційної політики.

Мета дослідження. Головна мета це спроба дослідити у широкому розумінні сутність корупції, роблячи висновки, опираючись на сучасні погляди науковців стосовно корупції, їі сфрери впливу на життя, наслідків; запропонувати авторське визначення поняття «Корупщія».

Виклад основного матеріалу. Щоб ефективно протидіяти корупційним злочинам, долати їх наслідки, не обійтися без всебічного вивчення та аналізу (дослідження) цього негативного явища. Безсумнівно, суспільству необхідно повне обгрунтоване наукове визначення поняття «Корупція» задля однозначного його трактування. Проте наразі деякі науковці підкреслюють, що уніфікація визначення «Корупщія» недоступна у сучасних умовах. Єдине поняття корупції та визначення універсального методу іiі протидії - складний процес, побудований на еволюції суспільства.

Проблема полягає ще і в тому, що корупщія проявляеться завжди по різному, змінними залишаються і ï причини, наслідки. У різноманітності проявів корупційних діянь вирішальне значення мають багато фракторів, серед яких традиції народу, етнічні особливості, релігійність та традиції, національність, менталітет. Не менш важливий фрактор - правові аспекти.

На сьогоднішній день можна виділити 2 основних підходи до тлумачення поняття «Корупція»: класичний та сучасний методи.

Класичний підхід до фрормування терміну «Корупція» користуеться задля загальної характеристики морально-етичного стану суспільства. Дотримувалися цих поглядів на корупційні правопорушення філософи Аристотель та Платон, політичний діяч Макіавеллі та історик Фукідід. Перша згадка про корупцію, як хабарництво та підкуп, належить до таких часових рамок, як розквіт цивілізації Межиріччя.

В політичному ключі поняття корупції вперше було використане Аристотелем, що визначив цю проблему, як тиранію (корумпованість фрорми монаршого правління). Соціальне визначення терміну «Корупція» популяризовано в римськоантичну епоху.

Сучасний підхід до тлумачення корупції грунтуеться на використанні 2 -х напрямків. Перший термін форомується у сенсі синоніму, розкриваючи подібні злочини продажністю службових діянь. Список посадових злочинних правопорушень постійно розширюеться, додаючи до класичного простого роз'яснення корупції (хабарництво та підкуп) такі дії, як підкуп виборців, розтрати коштів, вимагання, протекціонізм та багато іншого. Другий напрямок розглядає корупцію, як специфічність поведінки посадової особи, яка насамперед пов'язана зі зловживанням влади та службовим становищем в особистих цілях.

Найбільш точне, на нашу думку, тлумачення поняття «Корупщія» запропонував С. Невмержицький, що доцільно підкреслив дефініцію 3 точки зору законодавства. Корупція - це діяльність держслужбовців, що базуеться на зловживанні їх службовим становищем задля отримання незаконних пільг та прибутків матеріального характеру. Зловживання владою задля збагачення пов'язане з організованою злочинністю [8, с. 71].

Доктор юридичних наук В.О. Криволапчук [20] дає наступне визначення (характеристику) корупції. Це складне соціальне явище, що потрібно розглядати в багатьох аспектах (моральні, економічні та правові норми). Він підкреслює, що корупційні діяння в сучасному розумінні - розгалужена система злочинних відносин, що укорінилися окрім державних структур, у інших галузях. Зокрема, це кредитно-фрінансова та зовнішньоекономічні системи, всі ланки влади, діяльність бізнесу.

Історично склалося, що в Україні корупція розвивалася та процвітала (укріплювалася) досить тривалий час. Але в обігу серед провідних діячів та науковців термін "корупція" почав вживатися лише в 1913 році (робота А.Я. Естрін «Посадові злочини»). Реальні корупційні злочини (прояви продажності та підкупу чиновників державних установ) в Україні, з якими боролися правоохоронні органи протягом другого тисячоліття (друга половина цього проміжку часу), була оцінена А.Я. Естріном. Він зазначив, що спрощене визначення корупщії - продажність та можливість підкупу посадових осіб, державних чиновників, громадських діячів та політиків взагалі [4, с. 28].

Наукові діячі В.В. Кузьменко та М.В. Фоміна [21] зазначили у своїх напрацюваннях, що визначати термін корупцї, розглядати сутність цього явища потрібно у рамках взаємозв'язку цих правопорушень зі сфрерою суспільних відносин. 3 цього боку, корупщію можна трактувати, як особливий тип відносин обміну, до яких входять окремі громадяни та різні інститути. Всіх учасників корупційних взаємовідносин можна оцінити, як единий соціальний організм.

Багато науковців $[14 ; 15 ; 21]$ підкреслюють, що наведений приклад не може вважатися по- 
вним, бо не включає всі можливі прояви корупщії. Вчені-правознавці України говорять, що антикорупційна політика держави не може базуватися лише на протидії хабарництву, бо подібні правопорушення - одне 3 примітивних та відомих форм прояву корупційних злочинів. Корупційну сутність наразі має багата кількість злочинних діянь у різних сорерах життя, тому ці злочини підпадають під дію правового захисту держави.

Корупція активно проявляеться та укорінюеться не тільки у сорері муніципального та державного управління, а й активно використовується у приватному секторі. Правова система наразі не може точно кваліфрікувати подібні випадки корупційних схем, унеможливлюе правовий вплив на відносини приватного сектору.

Міжнародним співтовариством сформовані стандарти визначення корупції. Основна відмінність тлумачення корупції міжнародних конвенцій у порівнянні з українським законодавством - відсутність чіткості у визначенні поняття «Корупція». Для визначення корупційних відносин використовується перелік злочинів, що прийнято вважати корупційними. Дослідники погоджуються 3 подібним широким тлумаченням цього негативного явища, бо завдяки цьому на міжнародній правовій арені створено більше умов для застосування у широкому сенсі антикорупційного законодавства.

Палермська конвенція ООН проти транснаціональної організованої злочинності від 15 листопада 2000 р. вважає корупцію організованою злочинністю. У ній виділено 3 рівня корупційних діянь: в області державного управління; у сdpepi комерційних відносин; на високому рівні: у політиці, адміністращіях, фрінансових установах. Останній вид корупції має руйнівний вплив на економіку та державу в цілому.

В основу Конвенції ООН проти корупції покладені положення 3 Палермської Конвенції. Вона зазначає, що до переліку корупційних злочинів слід віднести: підкуп державних посадових осіб (іноземних та національних), осіб, що займають посади у міжурядових організаціях; розкрадання майна державною посадовою особою, неправомірне привласнення грошових коштів або нецільове використання майна; зловживання осіб в корисливих цілях свого службового становища; незаконне збагачення державної посадової особи; розкрадання майна чи коштів в приватному секторі, підкуп; відмивання доходів, що були отримані незаконним шляхом (через тіньові схеми); перешкоджання правосуддю.

Формулювання підходу до корупційних злочинів можна побачити в Міжнародному кодексі поведінки державних посадових осіб. Ці норми були прийняті 12 грудня 1996 р. резолющією Генеральної Асамблеї ООН. У цьому документі корупція представлена у «вчиненні особами певних дій чи бездіяльності при виконанні своїх посадових обов'язків, спроба вимагати чи приймати подарунки, що служать стимулом (обіцянкою) виконати незаконні дії, коли має місце така дія або бездіяльність».

У більш широкому сенсі уявлення про корупцію, що є негативним соціальним явищем, міститься в довідковому документі $\mathrm{OOH}$ про міжнародну боротьбу з корупцією. В ньому йдеться про те, що корупцію не можна вважати лише підкупом чи хабарництвом. Це зловживання державною владою, маючи на меті одержання вигоди в особистих інтересах. Рада Свропи визначає корупцію, як хабарництво та іншу поведінку осіб, на яких покладене виконання певних обов'язків приватного сектору чи держави, що призводить до вчинення державною посадовою особою, незалежним агентом чи приватним співробітником правопорушень, які мають на меті одержання для себе чи інших осіб будь-яких незаконних переваг (вигод).

Підсумовуючи міжнародно-правові тлумачення поняття корупщії, що викладені в офріційних документах Ради Свропи та ООН, визначення корупції наступне: це зловживання державною владою для особистих переваг (одержання матеріальних чи нематеріальних цінностей), в цілях груп та третіх осіб. Визначення допомагає зрозуміти, що корупція набагато ширша за хабарництво та підкуп. Вона охоплює непотизм (підтримка та заміщення вигідних (прибуткових) посад родичами та друзями) та численні форми привласнення суспільних коштів 3 метою особистого використання.

Антикорупційні міжнародні договори (Конвенції ООН проти корупції 2003 року [11], Конвенції Ради Європи про кримінальну відповідальність за корупцію 1999 року [12]) містять остаточно визначені норми, які стали після ратифрікації Україною цих міжнародних документів у 2006 році частиною української правової системи.

Найкоротше сучасне визначення корупції було сорормульовано Джозедом Сентуріа (Joseph Senturia): «зловживання суспільною владою заради вигоди». Сутність корупційних діянь в сучасних умовах, визначення їх змісту - досить складна задача для правової системи України. Наразі корупщія проникла в усі сфрери суспільних відносин. Так формуються стійкі формии, що здатні оманливо показати громадянам, що корупція - частина життя і їі неможливо подолати.

Не дивлячись на всі проблеми корупції та іï протидію в Україні, сутність цих діянь (внутрішній зміст) одна - це використання людиною своїх повноважень (влади) задля отримання «наживи». Подібні діяння демонструють деморалізацію суспільства, легковажне відношення до моральних принципів та законів.

Основа негативного ставлення до корупщї 3 давніх часів до сьогодення - раціональність особи, наділеною владою, її звички підпорядковуватися у роботі нормам права та моральним принципам. Подібні основи закликають провладних осіб (чиновників, депутатів, держслужбовців, підприемців та інших громадян) утримуватися від зловживання владою, відповідати принципам суспільного права (ніяк себе не виділяючи).

Тлумачний словник C.I. Ожегова містить наступну характеристику корупщії: «руйнування моральних засад у посадових осіб, політичних діячів, що виражається у хабарництві, протизаконному збагаченні, розкраданні, а також зрощуванні кримінальності» [3, с. 445].

У Великому тлумачному словникові сучасної української мови термін «Корупція» має декілька визначень: 
1. Це неправомірні діяння осіб, що уповноважені на виконання державних фонкцій, спрямовані на беззаконну експлуатацію наданих їм фрункцій (повноважень) 3 метою отримання від них послуг, матеріальних благ, а також інших вигод.

2. Це безпосередне користування посадовою особою свого становища з метою індивідуального збагачення.

3. Це підкупність, корумпованість держслужбовців, громадських фрункціонерів.

Юридична енциклопедія трактуе корупцію злочинним діянням в політичній сорері, державному управлінні, що базується на використанні службовцями владних повноважень, довірених їм посадових повноважень для власного збагачення [6].

Етимологічно «корупція» утворилась від 2 -х латинських слів "correi» та «rumpere». В перекладі correi - неминуча причетність до одніеї справи декількох представників сторін. Rumpere - руйнувати, порушувати, шкодити, розтлівати та скасовувати.

Характерна ознака корупційного злочину конфрлікт, що виникає між особистими інтересами працедавця посадової особи та їі діями. Це може бути конфліктна ситуація між суспільними інтересами та діями конкретної особи. Найчастіше корупційні правопорушення можна віднести до шахрайства проти державної влади.

Юридичний словник Генрі Блека корупцію визначає наступним чином: «це дія всупереч прав та обов'язків, що не сумісна зі службовими обов'язками особи, яка неправомірно користується власним статусом 3 метою отримання вигод та інших переваг собі чи іншим особам» [7].

I.Ю. Тимофеєва вважає, що корупщію може вчинити будь-яка людина, у якої є влада користування ресурсів. Якщо службовець починає діяти на свій розсуд, нехтуючи своїми посадовими обов'язками, моральністю та законом, це і є корупційний злочин. Його можуть вчинити співробітник правоохоронних органів, лікар, викладач, бізнесмен, суддя, депутат, чиновник та інші особи. Головний стимул до вчинення корупщійних злочинів - шанс отримати прибуток (економічну вигоду) завдяки використанню повноважень. Головний чинник, який може спинити корупціонерів, - ризик викриття злочину, страх отримати покарання за правопорушення [3, с. 5].

Профресору Н.В. Кузнєцову належить думка, що корупцію не можна визначати у вузькому сенсі (як правовий злочин). Необхідно розглядати корупційні діяння, як економічне, соціальне явище, засноване на порушенні норм моралі. Вони шкодять фрункціонуванню на державному рівні правових відносин, моральних норм суспільства [9, с. 21-26; 10, с. 106]. 3 цього можна зробити наступний висновок: сутність корупції - природа людини, яка здатна робити вчинки в певних обставинах, всупереч принципам виховання та моралі.

Проблема процвітання корупції у межах України полягає в тому, що, не дивлячись на проголошення побудови держави на основі принципів демократії та права (як у розвинутих Європейських країнах), наразі законом легалізуються суспільні корупційні відносини. Суспільство розглядає прагнення нажитися - нормою поведінки, що повністю суперечить концепції побудові демократичної держави, верховенства права.

Проблема поглиблюеться тим, що корупціонери (чиновники, підприемці та інші особи) вважають свої прагнення до збагачення - демократичними правами. Ця думка спотворюе принципи демократії, культури, моральності. Наразі вчені та дослідники опрацьовують наукове осмислення ціеї негативної складової українського суспільства задля об'єктивної оцінки та розробці едективних методів протидії корупщії.

Деякі країни Європи (наприклад, Данія та Фінляндія) не використовують поняття корупції. Воно розкривається в окремих правопорушеннях, прописаних у законодавстві. Зокрема, Франція терміном «Корупція» позначає близько 20-ти складників кримінальних злочинів. В сукупності подібні правопорушення мають кваліфрікуючи ознаки - забезпечення безпідставних благ (ст. 432-14 Кримінального кодексу), незаконне використання довіри фрірми чи майна (ст. 425-4, 437-3, 460, 464 Закону про компанії) чи інших [20, с. 19].

Розмите визначення корупції у законодавствах України та інших держав викликає у наукових колах, серед юристів-практиків певні дискусії. Протиріччя викликае норма, яка вважає корупцією прийняття пропозиції чи обіцянка неправомірної дії. Логічно сорормулювати, що корупційний злочин є згода на одержання неправомірної вигоди у будь-якій існуючій фрормі: усна домовленість, письмова угода чи інший вид. Проблема полягає в тому, що для притягнення корупціонера до відповідальності потрібно довести фракт корупщії. Якщо «обіцянку» в письмовій формі можна вважати доказом вчинення правопорушення, то підтвердити усну згоду неправомірних дій посадової особи майже неможливо.

Ст. 1 Закону «Про боротьбу з корупцією» від 05.10.1995 [17] визначае корупщію діяльністю осіб, що виконують свої посадові обов'язки (функції держави), спрямованою на одержання протизаконним шляхом послуг, благ матеріального характеру, пільг чи інших переваг. Багато проблем стосуються визначення протизаконної дії державного службовця, бізнесмена чи іншої особи декількома поняттями "корупція», «корупційні діяння». Оперуючи терміном «діяння» («діяльність»), основуючись на разновекторність його тлумачення, можна уникнути відповідальності. На законодавчому рівні корупція розглядається в единій формі - коли особа одержуе відповідні предмети.

Дискусій вдалося уникнути прийняттям Закону України «Про засади запобігання і протидії корупціï» [16], який набрав чинності 01.07.2011 p. У ньому у ст. 1 закріплено визначення поняття корупції: це використання суб'єктом відповідальності у корупційних злочинах посадових можливостей, мета яких - отримання незаконної вигоди чи обіцянка вчинення правопорушень задля вигоди особистої чи інших осіб. Беззаконне застосування даних особі посадових можливостей може стосуватися фрінансових ресурсів, інших переваг та привілеїв, пільг, нематеріальних активів. Корупційне правопорушення - умисна протизаконна дія з ознаками корупщії, що вчи- 
няється суб'єктом відповідальності, за яку законодавством установлене адміністративне, кримінальне, цивільно-правове чи дисциплінарне покарання [1].

Більшість країн світу розширюе поняття корупції, підкреслюючи, що це не просто хабарництво, а й інші прояви («кумівство», різні незаконні форми привласнення публічних грошей, патронаж).

У вітчизняній правовій системі поняття «Корупція» розмите (нечітко визначене). Однак відсутність нормативного визначення подібних злочинів не може стати перешкодою для правової оцінки правопорушень.

Викладене дослідження дозволяе зробити деякі висновки. Специфічність визначення корупції наразі має відображати окремі сторони об'єкта. Вивчення проблем корупції у багатоаспектному розумінні (моральне, політичне та соціально-економічне явище), об'єднання злочинів у комплекс неетичних та протиправних дій дозволить розширити сприйняття корупції, як негативного явища на теренах України.

Висновки. На сьогоднішній день не існуе чіткого розуміння змісту та сутності корупційних злочинів для всіх політичних систем.

Корупцію характеризують універсальним явищем, яке недостатньо досліджене будь-якою галуззю. Її потрібно досліджувати комплексно, враховуючі правові аспекти, фрілософські, соціальні, а також економічні характеристики.

На нашу думку, поняття «Корупція» - протизаконна експлуатащія особою власних владних повноважень (посадового становища) з метою отримання вигоди матеріального чи нематеріального характеру у власних інтересах або для інших осіб.

В антикорупційному законодавству України визначення «Корупція» перевантажене кримінально-правовими ознаками. Це поняття не торкається багатьох сорер, де корупційна діяльність укорінилася.

Традиційне трактування корупції має істотний недолік, що зумовлюеться вузьким підходом, коли держава - одна величезна корупційна схема, а державний службовець - корупціонер, що має певні обов'язки, які можна використовувати задля особистої вигоди. В цьому випадку інша сторона корупції залишається непоміченою (знаходиться у тіні). Розмежування виключно в соціально-економічній системі влади та бізнесу оправдане, але це не дозволяе відображати зміни політичної системи України.

Поняття корупції, виявлення її сутності необхідно аналізувати у контексті взаємозв'язку певної сфери суспільних взаємовідносин. Зокрема, корупцією вважаеться особливий тип взаємного обміну, що пов'язуе окремих людей, різні установи в едину соціальну одиницю.

\section{Список літератури:}

1. Великий тлумачний словник сучасної української мови / уклад. і голов. ред. В.Т. Бусел. Київ, Ірпінь, 2009. $1736 \mathrm{c}$.

2. Ожегов С.И., Шведова Н.Ю. Толковый словарь русского языка. 4-е изд., доп. Москва : А ТЕМП, 2006.944 с.

3. Тимофеева И.Ю. Методы противодействия коррупции: советы предпринимателям. Смоленск : НП ЕСБР, 2010. 68 c.

4. Эстрин А.Я. Должностные преступления. Москва, 1928. С. 28.

5. Макухін О.О. Поняття корупції в Україні та ЄC: порівняльний аналіз, адміністративно-правовий аспект. Ученые записки Крылского фбедерального университета илени В И. Вернадского. Юридические науки, 2013. № 2-1 (2). С. 55-61.

6. Юридична енциклопедія : в 6 т. Т. 3 / Редкол.: Ю.С. Шемшученко (голова редкол.) та ін. Київ : «Укр. енцикл.», 1998. $741 \mathrm{c}$.

7. Про засади запобігання і протидії корупщії : Закон України № 3206-VI від 7 квітня 2011 року. URL: https://zakon.rada.gov.ua/laws/show/3206-17\#Text (дата звернення: 01.02.2021).

8. Невмержицький Є.В. Корупція в Україні: причини, наслідки, механізми протидії. Київ, 2008. 368 с.

9. Кузнецова Н.Ф. Коррупция в системе уголовных преступлений. Вестник МГУ. Сер. 11. 1993. № 1. С. $21-26$.

10. Будатаров C.M. Понятие коррупции в российском законодательстве и юридической литературе. Вестн. Tол. гос. yн-ma. 2012. № 359. URL: https://cyberleninka.ru/article/n/ponyatie-korruptsii-v-rossiyskomzakonodatelstve-i-yuridicheskoy-literature (дата звернення: 01.03.2021).

11. Конвенція Організації Об'єднаних Націй проти корупції : міжнародний документ від 31.10.2003. Biдомості Верховної Ради, 2007. № 49.

12. Конвенція Ради Свропи про кримінальну відповідальність за корупщію 1999 p. URL: http://zakon.rada.gov.ua (дата звернення: 01.02.2021).

13. Клімова C.M. Організація запобігання та протидії корупції в Україні. Харків, 2012. 283 с.

14. Побережний В.В. Сутність та причини корупції в системі органів державної влади. URL: http://www.academy.gov.ua/ej/ej12/txts/10pwodv.pd0f (дата звернення: 01.02.2021).

15. Політова А.С. Поняття корупції: проблеми визначення. Порівняльно-аналітичне право. 2013. № 3-2. C. $268-272$.

16. Про запобігання корупції : Закон України № 1700-VII від 14.10.2014 p. URL: http://zakon2.rada.gov.ua/laws/ show/1700-18 (дата звернення: 01.02.2021).

17. Закон України "Про боротьбу з корупцією" (1995 рік) № 356/95-BP від 05.10.1995. URL: zakon.rada.gov.ua/ laws/show/356/95-\%D0\%B2\%D1\%80/ed19951005\#Text (дата звернення: 01.02.2021).

18. Кодекс поведінки посадової особи щодо підтримання правопорядку : резолюція 34/169 Генеральної асамблеї ООН від 17.12.1979 p. URL: http://zakon4.rada.gov.ua/laws/show/995282 (дата звернення: 01.02.2021).

19. Цивільна конвенція про боротьбу з корупцією : прийнята Комітетом міністрів Ради Європи 04.11.1999 р. URL: http://zakon.rada.gov.ua/cgi-bin/laws/main.cgi?nreg=994102 (дата звернення: 01.02.2021).

20. Соціально-психологічні аспекти виявлення і попередження корупції та інших правопорушень серед працівників міліції / за заг. ред. В.О. Криволапчука. Вінниця : ВНТУ, 2009.134 с.

21. Фоміна М.В., Кузьменко В.В. Сутність, форми і класифікація корупційних відносин. Еконолічний вісник університету. 2013. Вип. 21(1). С. 182-186. URL: http://nbuv.govua/UJRN/ecvu201321(1)31 


\section{References:}

1. Busel V.T. (2009) Velikii tlumachnii slovnik suchasnoi ukrains'koi movi [Large explanatory dictionary of the modern Ukrainian language]. Kyiv. (in Ukrainian)

2. Ozhegov S.I., Shvedova N.Yu. (2006) Tolkovyiy slovar russkogo yazyika [Explanatory dictionary of the Russian language]. 4-e izd., dop. Moskva: A TEMP. (in Russian)

3. Timofeeva I.Yu. (2010) Metodyi protivodeystviya korruptsii: sovetyi predprinimatelyam [Anti-corruption methods: tips for entrepreneurs]. Smolensk: NP ESBR. (in Russian)

4. Estrin A.Ya. (1928) Dolzhnostnyie prestupleniya [Official crimes]. Moskva. (in Russian)

5. Makukhin O.O. (2013) Ponyattya koruptsii v Ukraini ta ES: porivnyal'nii analiz,administrativno-pravovii aspekt [The concept of corruption in Ukraine and the EU: a comparative analysis, administrative and legal aspect]. Uchenye zapiski Krymskogo federal'nogo universiteta imeni V.I. Vernadskogo. Yuridicheskie nauki, no. 2-1 (2), pp. 55-61.

6. Shemshuchenko Yu. S. (1998) Yuridichna entsiklopediya [Legal Encyclopedia]: v 6 t. T. 3. Kyiv: «Ukr. entsikl». (in Ukrainian)

7. Law of Ukraine Pro zasadi zapobigannya i protidii koruptsii no. 3206-VI vid 7 kvitnya 2011 roku. URL: https://zakon.rada.gov.ua/laws/show/3206-17\#Text (accessed 01 February 2021).

8. Nevmerzhits'kii E.V. (2008) Koruptsiya v Ukraini: prichini, naslidki, mekhanizmi protidii [Corruption in Ukraine: causes, consequences, mechanisms of counteraction]. Kyiv. (in Ukrainian)

9. Kuznetsova N.F. (1993) Korruptsiya v sisteme ugolovnykh prestuplenii [Corruption in the criminal system]. Vestnik MGU. Ser. 11, no. 1, pp. 21-26.

10. Budatarov S.M. (2012) Ponyatie korruptsii v rossiiskom zakonodatel'stve i yuridicheskoi literature [The concept of corruption in Russian legislation and legal literature]. Vestn. Tom. gos. un-ta, no. 359. URL: https://cyberleninka.ru/ article/n/ponyatie-korruptsii-v-rossiyskom-zakonodatelstve-i-yuridicheskoy-literature (accessed 01 March 2021).

11. International Document (2007) Konventsiya Organizatsii OB'ednanikh Natsii proti koruptsii vid 31.10.2003. Vidomosti Verkhovnoi Radi, no. 49 (accessed 01 March 2021).

12. Konventsiya Radi Evropi pro kriminal'nu vidpovidal'nist' za koruptsiyu (1999). URL: http://zakon.rada.gov.ua (accessed 01 March 2021).

13. Klimova S.M. (2012) Organizatsiya zapobigannya ta protidii koruptsii v Ukraini [Organization of Prevention and Counteraction to Corruption in Ukraine]. Kharkiv. (in Ukrainian)

14. Poberezhnii V.V. Sutnist' ta prichini koruptsii v sistemi organiv derzhavnoi vladi [The essence and causes of corruption in the system of public authorities]. URL: http://www.academy.gov.ua/ej/ ej12/txts/10pwodv.pdOf

15. Politova A.S. (2013) Ponyattya koruptsii: problemi viznachennya [The concept of corruption: problems of definition]. Porivnyal'no-analitichne pravo, no. 3-2, pp. 268-272.

16. Law of Ukraine Pro zapobigannya koruptsii № 1700-VII vid 14.10.2014 r. URL: http://zakon2.rada.gov.ua/laws/ show/1700-18

17. Law of Ukraine Pro borot'bu z koruptsieyu (1995 rik) № 356/95-VR vid 05.10.1995. URL: https://zakon.rada.gov.ua/ laws/show/356/95-\%D0\%B2\%D1\%80/ed19951005\#Text

18. Kodeks povedinki posadovoi osobi shchodo pidtrimannya pravoporyadku: rezolyutsiya 34/169 General'noi asamblei OON vid 17.12.1979 r. URL: http://zakon4.rada.gov.ua/laws/show/995282

19. Tsivil'na konventsiya pro borot'bu z koruptsieyu: priinyata Komitetom ministriv Radi Evropi 04.11.1999 r. URL: http://zakon.rada.gov.ua/cgi-bin/laws/main.cgi?nreg=994102

20. Krivolapchuka V.O. (2009) Sotsial'no-psikhologichni aspekti viyavlennya i poperedzhennya koruptsii ta inshikh pravoporushen' sered pratsivnikiv militsii. [Socio-psychological aspects of detection and prevention of corruption and other offenses among police officers]. Vinnitsya: VNTU. (in Ukrainian)

21. Fomina M.V. (2013) Sutnist', formi i klasifikatsiya koruptsiinikh vidnosin [The essence, forms and classification of corruption relations]. Ekonomichnii visnik universitetu, vol. 21(1), pp. 182-186. 